УДК 681.7.069.24

\title{
C.B. Сандер
}

Кафедра хірургї̈ медичного факультету № 2 (зав. - проф. О.С. Каніковський)

Вінницького національного медичного університету імені М.І. Пирогова

\section{ПОРІВНЯЛЬНА ХАРАКТЕРИСТИКА ЛАЗЕРНӦ̈ ФОТОПЛЕТИЗМОГРАФІЇ ТА ЛАЗЕРНОЇ ДОПЛЕРІВСЬКОЇ ФЛОУМЕТРІЇ В ДОСЛІДЖЕННІ КРОВОПОСТАЧАННЯ СТОПИ}

\begin{abstract}
Резюме. Мета - порівняльна оцінка діагностичної цінності лазерної фотоплетизмографії та доплерівської флоуметрії в дослідженні кровопостачання стопи у хворих на хронічну ішемію нижніх кінцівок. Серед 29 осіб без ішемії високоамплітудний пульсуючий плин крові мали 28 , низькоамплітудний пульсуючий - 1. При стабільній ішемії (49 пацієнтів) високоамплітудний пульсуючий плин крові мали 22 , низькоамплітудний - 26, непульсуючий - 1. При прогресуючій ішемії (61 хворий) 7 мали низькоамплітудний пульсуючий плин крові, 54 - непульсуючий. Ці результати корелюють із результатами допплерівської флоуметрії. Отже, лазерна фотоплетизмографія - високоінформативний метод, що дозволясоцінити стан кровопостачання стопи, визначити тип плину крові та перспективи збереження. Найінформативний показник - пульсуючий кровоплин. При прогресуючій ішемії його чутливість - 88,5\%, специфічність - 96,6\%, прогностична цінність - 91,6\%.
\end{abstract}

Ключові слова: кровообіг стопи, лазерна фотоплетизмографія, лазерна допплерівська флоуметрія.

Під час обстеження хворих на хронічну ішемію нижніх кінцівок серед першочергових постає завдання оцінити резерви колатерального кровообігу та стан місцевого кровоплину, зокрема на стопі. Для дослідження застосовують транскутантну оксиметрію, капіляроскопію, сцинтиграфію та інші $[1,2]$. Ці методи відображають стан компенсаторних механізмів кровообігу кінцівки, що опосередковано дає інформацію про розвиток колатерального кровообігу. Але вкрай недостатню увагу приділяють дослідженню тонусу судин і характеру місцевого кровоплину як прогностичних чинників збереження органу. Їх результати не дозволяють відрізнити зміни на грунті мікро- і макроангіопатії. Усе більшого розвитку набувають методи 3 оптичною реєстрацією, зокрема лазерна допплерівська флоуметрія (ЛДФ) та лазерна фотоплетизмографія (ЛФПГ) [1-5].

Мета дослідження: провести порівняльну оцінку діагностичної цінності ЛФПГ та ЛДФ в дослідженні кровопостачання стопи, зокрема у хворих на хронічну ішемію нижніх кінцівок.

Матеріал і методи. Обстежено 139 осіб. У 49 хворих відзначали стабільний перебіг хронічноі ішемії, у 61 - прогресуючий. У контрольну групу увійшли 29 осіб без ознак хронічної ішемії. Проводили фізикальне, клініко-лабораторне обстеження та ультразвукове дуплексне скану-вання.
Для оиінки місиевого кровоплину проводили ЛДФ $i$ ЛФПГ. Визначали характер плину крові на основі отриманого сигналу. Регулярний імпульсний високоамплітудний сигнал відповідав пульсуючому великооб 'ємному кровоплину, регулярний низько амплітудний сигнал - пульсуючому малооб'ємному кровоплину, хаотичний монофазний низькоамплітудний сигнал - непульсуючому малооб'смному кровоплину (рис. 1).

Основними місиями дослідження були I пальиі кисті та стопи, рівень передплесноплесного суглоба та середньої третини гомілки. У сумнівних випадках очінювали зміну сигналу в умовах постоклюзійної проби. На підставі отриманих даних, розраховували чутливість, специфічність $i$ прогностичну цінність ЛФПГ [6].

Результати дослідження та їх обговорення. У обстежених хворих контрольної групи пульс визначали на всіх рівнях нижніх кінцівок. Шкіра стоп була теплою, блідо-рожевою. Реактивна гіперемія на кисті виникала за 2-8 с при тиску 100140 мм рт ст. На стопі реактивна гіперемія виникала за 4-14 $(9,1 \pm 0,4)$ с при тиску 100-160 мм рт ст. При ЛФПГ на всіх рівнях реєстрували регулярний високо- (28 осіб) або низькоамплітудний (1 особа) сигнал. Амплітуда сигналу на I пальці стопи становила $(78,4 \pm 3,7) \%$ від амплітуди сигналу I пальця кисті $(\mathrm{p}<0,05)$. У проекції артерій, 


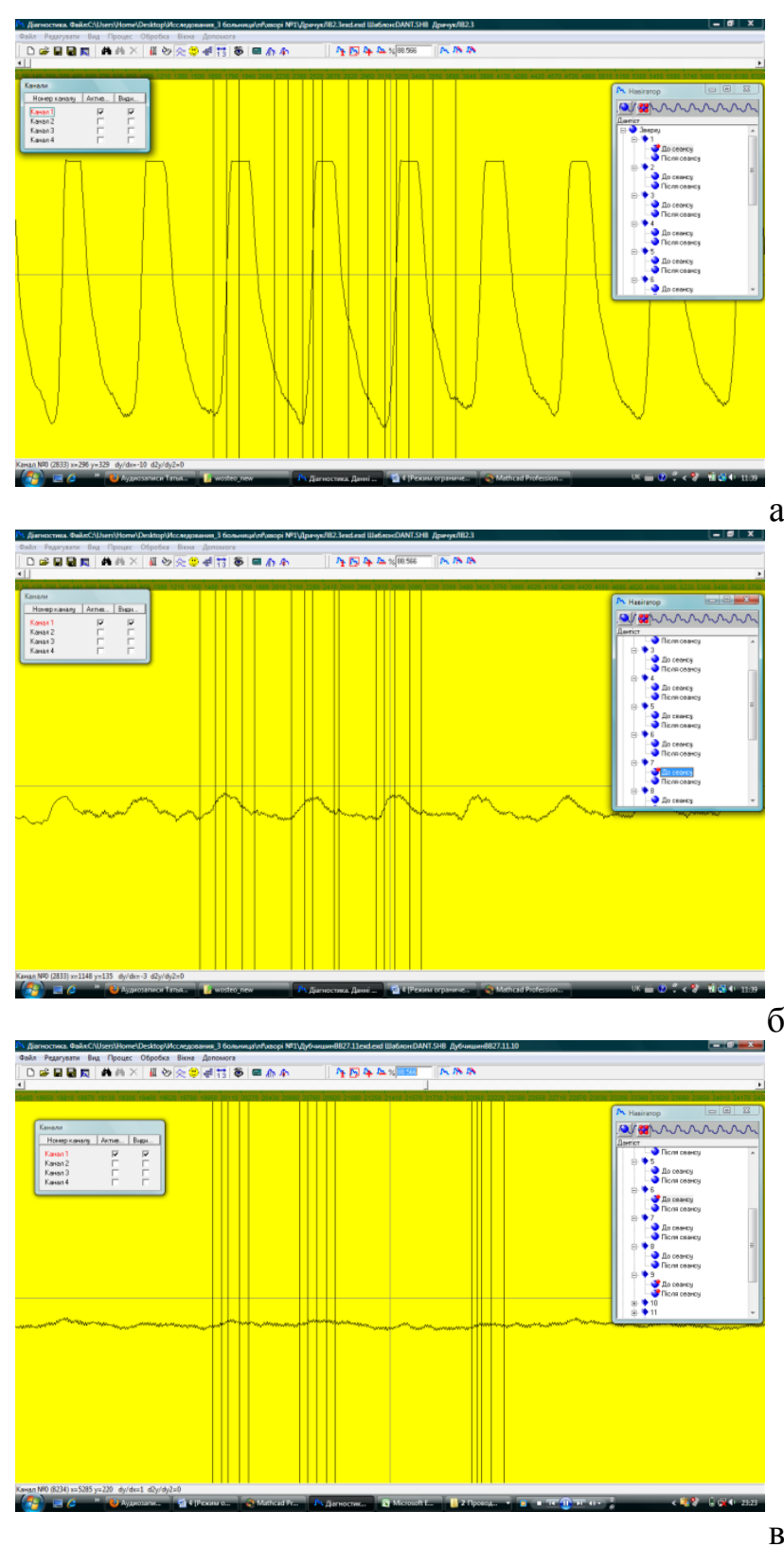

Рис. 1. Визначення характеру плину крові: $a$ - пульсуючий великооб'ємний; б - пульсуючий малооб 'ємний;

$$
\text { в-непульсуючий }
$$

де пальпаторно визначали їх пульсацію, реєстрували високоамплітудний регулярний сигнал. При проведенні постоклюзійної проби відзначали швидке $(7,9 \pm 0,3$ c) зростання амплітуди сигналу на $62,3 \pm 3,9 \%$.У 3 пацієнтів через наявність набряку в ділянці гомілковостопного суглоба пальпаторно пульсацію на задній великогомілковій артерії і артерії тилу стопи не визначали. При ЛФПГ у проекції цих артерій реєстрували високоамплітудний, регулярний сигнал, при УЗ-скануванні - магістральний кровоплин.

Хворі зі стабільним перебігом хронічної ішемії відзначали мерзлякуватість стоп, парестезії і гіпотермію шкіри стоп. Шкіра стоп була бліда, але помірно тепла. Дистанція ходьби дорівнювала 140-240 м. Реактивна гіперемія на кисті виникала за 4-10 с при тиску1 10-170 мм рт. ст. На стопі реактивна гіперемія виникала за 17-73 $(28,0 \pm 2,2)$ с $(\mathrm{p}<0,01)$ при тиску 70-120 мм рт. ст. За даними УЗ сканування переважали $(89,8 \%)$ однорівневі оклюзії. У магістральних артеріях нижче рівня оклюзії виявляли колатеральний компенсований або магістральний змінений плин крові. При ЛФПГ у 22 реєстрували регулярний високоамплітудний сигнал, у 26 - регулярний низькоамплітудний, у 1 - хаотичний монофазний низькоамплітудний. Амплітуда сигналу на I пальці стопи становила $38,6 \pm 2,3 \%$ від амплітуди сигналу I пальця кисті $(\mathrm{p}<0,05)$. При проведенні постоклюзійної проби відзначали швидке $(21,8 \pm 1,9$ с) зростання амплітуди сигналу на $41,6 \pm 3,4 \%$. При ЛФПГ в проекції артерій, нижче рівня оклюзії, реєстрували низькоамплітудний, регулярний сигнал, при УЗ скануванні - колатеральний компенсований кровоплин. ЛДФ була проведена у 4 хворих. У всіх хворих був зареєстрований імпульсний регулярний високоамплітудний сигнал. При проведенні постоклюзійної проби відзначали швидке (16-24 c) зростанням амплітуди сигналу на 94$132 \%$.

Хворі із прогресуючою ішемією постійно відчували холод і парестезії у стопі та біль у спокою, що примушувало періодично опускати ногу. Шкіра стоп була холодною, блідою, блідо-синюшною або багровою, часто мармуровою. У 43 хворих відзначали набряк стопи. Некротичні зміни пальців і стопи мали 19 хворих. Дистанція ходьби становила не перевищувала 50 м. Реактивна гіперемія на кисті виникала за 4-12 с при тиску 100180 мм рт. ст., на стопі - за 62-300 $(136,3 \pm 4,7)$ с $(\mathrm{p}<0,01)$ с при тиску нижчому за 50 мм рт. ст.За даними УЗ сканування, переважали $(85,2 \%)$ багаторівневі оклюзії, в магістральних артеріях нижче рівня оклюзії плин крові був колатеральний некомпенсований або відсутній. При ЛФПГ у 7 пацієнтів реєстрували регулярний низькоамплітудний сигнал, у 54 - хаотичний монофазний низькоамплітудний сигнал. У проекції артерій, в яких пальпаторно не визначали пульсацію, при ЛФПГ реєстрували хаотичний монофазний низькоамплітудний сигнал. Амплітуда сигналу на I пальці стопи не перевищувала 25\% від амплітуди сигналу I пальця кисті і становила $10,7 \pm 1,9 \%$ $(\mathrm{p}<0,05)$. На гомілці реєстрували регулярний переривчастий низькоамплітудний сигнал із співвідношенням гомілка/передпліччя $0,21 \pm 0,08$. При проведенні постоклюзійної проби відзначали повільну $(76,7 \pm 1,4$ с) реакцію із зростанням амплі- 
туди сигналу на $17,8 \pm 3,7 \%$. У 23 хворих росту амплітуди сигналу не відзначали. У трьох хворих під час проведення постоклюзійної проби хаотичний монофазний, низькоамплітудний сигнал перетворювався у регулярний імпульсний i амплітуда його зростала на $69-173 \%$. ЛДФ проведена у 6хворих. У 1 хворого зареєстрований імпульсний регулярний низькоамплітудний сигнал, у 5 - монофазний. При проведенні постоклюзійної проби відзначали повільне (понад 60 с) зростанням амплітуди сигналу на $12-53 \%$.

Спроби ампутації на рівнях, з яких отримували монофазний низькоамплітудний сигнал (7 осіб), були безуспішними. Ампутація гомілки/стопи були успішними при отримані з відповідного рівня регулярного імпульсного сигналу.

Отже, пульсуючий великооб'ємний кровоплин зареєстрований у 50 пацієнтів (28 без ознак хронічної ішемії та 22 зі стабільним їі перебігом), пульсуючий малооб'ємний - у 34 пацієнтів (1 без ознак хронічної ішемії, 26 зі стабільним іiї перебігом та 73 прогресуючим), непульсуючий малооб'ємний - у 55 пацієнтів (1 зі стабільним іï перебігом хронічної ішемії та 7 з прогресуючим). У діагностиці хронічної ішемії нижніх кінцівок специфічність відсутності пульсуючого плину крові становила 100\%, великооб' ємногопульсуючого - 96,6\%. Чутливість непульсуючого плину крові при прогресуючій ішемії становила 88,5\%, відсутності великооб'ємного пульсуючого - 100\%. Прогностична цінність відсутності пульсуючого плину крові при прогресуючій ішемії становила 91,6\%.

За даними інших дослідників, специфічність і чутливість ЛДФ досягає $80 \%[7,8]$. Як бачимо, показники відрізняються незначно. Деяку розбіжність ми пов'язуємо із відмінностями у фізичних принципах цих методів. Метод ЛДФ грунтується на вимірюванні доплерівського компонента в спектрі відбитого лазерного сигналу, який розсіяний на рухливих еритроцитах, що проходять крізь одиницю об“єму тканини за одиницю часу. Амплітуда сигналів формується від усіх еритроцитів, що знаходяться в ділянці зондування і рухаються 3 різною швидкістю і по-різному кількісно розподілені в артеріолах, капілярах, венулах і артеріовенулярних анастомозах. Його результати безпосередньо залежать від швидкості і типу (турбулентне, ламінарне) і напрямку руху еритроцитів (судини і потоки у них у місці дослідження орієнтовані в різних напрямках), показника капілярного гематокриту і кількості функціонуючих капілярів. Метод ЛДФ дозволяє оцінювати компоненти тонусу мікросудин на основі величин амплітуд коливання мікрокровоплину, що зумовлені інтенсивністю скорочень м'язової стінки судин, а отже, і діаметром просвіту судин $[4,5]$. Метод ЛФПГ грунтується на оцінці зміни об“єму тканин у місці дослідження, що відбиває рух судинної стінки під впливом потоку. Тонус судинної стінки при ЛФПГ оцінюють на підставі іï реакції на зміни характеристик потоку, зокрема при проведенні постоклюзійної та інших проб [3]. 3 цим же ми пов'язуємо і те, що у хворих із стабільним перебігом ішемії показники ЛДПГ були дещо вищими, ніж показники ЛДФ, а при прогресуючій ішемії - навпаки.

До переваг ЛФПГ можна віднести більшу чутливість до пульсативності кровоплину, що найбільш чітко проявляється в умовах прогресування ішемї.

Висновки. 1. Результати, що отримані при проведенні ЛФПГ, корелюють із результатами, що отримані при проведенні ЛДФ. 2. ЛФПГ - високоінформативний метод, що дозволяє оцінити стан кровопостачання стопи, визначити пульсативність плину крові в різних їі ділянках та перспективи збереження. Найінформативний показник пульсуючий кровоплин. Його чутливість при прогресуючій ішемії становила 88,5\%, специфічність - 96,6\%, прогностична цінність - 91,6\%.

Перспективи подальших наукових досліджень. Планується подальше розроблення алгоритму комплексного обстеження кровоплину на стопі для оцінки перспективи ії збереження.

\section{Список використаної літератури}

1. Діагностика та лікування хронічної критичної ішемї нижніх кінцівок, поєднаної з мультифокальним атеросклерозом [метод рекомендації] / В.Г. Мішалов, М.П. Бойчак, В.А. Черняк [та ін.]. - К.: НМУ ім. О.О. Богомольия, 2007. - 62 с. 2. Сухарев И.И. Хирургия атеросклероза сосудов у больных сахарным диабетом / И.И.Сухарев. - К.: 1995. - 295 с. 3. Фотоплетизмографічні технології контролю сериево-судинної системи: [монографія] / С.В. Павлов, В.П. Кожем'яко, В.Г. Петрук, П.Ф. КолісникВінниия: УНІВЕРСУМ-Вінничя, 2007. - 254 с. 3. Лазерная допплеровская флоуметрия микрочиркуляцчии крови: [руководство для врачей/ под ред. Крупаткина А.И., Сидорова В.В.]. - М.: Медицина, 2005. - 125 c. 4. Лазерная допплеровская флоуметрия в оценке состояния и растройств микроциркуляции крови [метод пособие для врачей] / [Козлов В.И., Азизов Г.А., Гурова О.А., Литвин Ф.Б.]. - М.: Российский ун-т дружбы народов, 2012. - 34 c. 5. Altman D.G. Statistics Notes: Diagnostictests 1: sensitivity and 
specificity / D.G. Altman, J.M. Bland // BMJ. - 1994. - Vol. 308 (11 June). - P. 1552. 6. Лазерная допплеровская флоуметрия в оченке состояния кожной микрочиркулящии крови у паџиентов с сахарным диабетом: (II Всероснауч форум молодых ученых "Наука будущего - наука молодых”) [Електронний ресурс] / Д.А.Куликов // Режим доступу: https://4science.ru levents/fy2016/experts/aa2846f716bd45c8b8ad03ef46245b42 (C) 4science. 7. Оченка микрочиркуляторных нарушений нижних конечностей и ее влияние на выбор хирургической тактики у больных с синдромом диабетической стопы / В.А. Ступин, В.В. Михальский, А.И. Аникин [та ін.] // РМЖ. Урология. Хирур-гия. - 2008. - № 14. - C. 962-967.

\section{СРАВНИТЕЛЬНАЯ ХАРАКТЕРИСТИКА ЛАЗЕРНОЙ ФОТОПЛЕТИЗМОГРАФИИ И ЛАЗЕРНОЙ ДОППЛЕРОВСКОЙ ФЛОУМЕТ- РИИ В ИССЛЕДОВАНИИ СОСТОЯНИЯ КРОВОСНАБЖЕНИЯ СТОПИ}

Резюме. Цель - сравнительная оценка диагностической ценности лазерной фотоплетизмографиии допплеровской флоуметрии в исследовании кровоснабжения стопы у больных хронической ишемией нижних конечностей. Среди 29 лиц без ишемии высокообъёмный пульсирующий кровоток был у 28 , низкообъёмный пульсирующий - у 1 . При стабильной ишемии (49 больных) высокообъёмный пульсирующий кровоток был у 22 , низкообъёмный пульсирующий- у 26 , непульсирующий - у 1. При прогрессирующей ишемии (61 больной) у 7 был низкообъёмный пульсирующий кровоток, у 54 - непульсирующий. Эти результаты коррелировали с результатами ЛДФ. Таким образом, ЛФПГ - высокоинформативный метод, позволяющий оценить кровоснабжение стопы, установить тип кровотока и перспективы сохранения. Наиболее информативный показатель пульсирующий кровоток. При прогрессирующей ишемии его чувствительность - $88,5 \%$, специфичность $-96,6 \%$, прогностическая ценность $-91,6 \%$. Ключевые слова: кровообращение стопи, лазерная фотоплетизмография, лазерная допплеровская флоуметрия.

\section{COMPARATIVE CHARACTERISTICS OF LA- SER PHOTOPLETHYSMOGRAPHY AND LA- SER DOPPLER FLOWMETRY FOR TESTING OF FOOT BLOOD SUPPLY}

Abstract. The aim was to asses the diagnostic value of laser photoplethysmography and laser Doppler flowmetry for testing of foot blood supply in patients with chronic occlusive diseases of the lower extremities arteries. Among 29 individuals without ischemia high amplitude of blood flow was determined in 28 cases, and low amplitude - in one case. In case of stable ischemia (49 patients) high volume pulsating blood flow was found in 22 cases, and low volume in 26 cases, non-pulsatiing - in one case. Patients with progressive ischemia (61 patients) had low volume ( 7 cases) pulsating blood flow, and 54 cases non-pulsating blood flow. These results correlated to LDF findings. Thus, LPPG is high informative method for testing of foot blood supply, determining the kind and possibilities of foot saving. The most informative sign is pulsatile blood flow. In progressive ischemia its sensitivity is $88.5 \%$, specificity is $96.6 \%$, prognostic value is $91.6 \%$.

Key words: foot blood supply, laser photoplethysmography, laser Doppler flowmetry.

Vinnytysa National Pirogov Memorial Medical University (Vinnytsya)

Надійшла 23.02. 2017 p. Рецензент - проф. Домбровський Д.Б. 